\title{
Herpetofauna of the opencast mines in Lower Silesia (Poland)
}

\author{
Monika WIRGA and Tomasz MAJTYKA \\ Department of Evolutionary Biology \& Conservation of Vertebrates, University of Wroctaw, \\ Sienkiewicza 21; 50-335 Wrocław, Poland; e-mail: monika.wirga@gmail.com; tomasz.majtyka@uni.wroc.pl
}

\begin{abstract}
Herpetofauna of opencast mines is poorly known and no comprehensive research has been previously carried out in this field. On the example of Lower Silesia this study aims to investigate this fauna. Observations, conducted in 22 different opencast mines in the eastern, lowland part of Lower Silesia (SW Poland), resulted in identification of a total of 19 species (14 amphibian species and 5 reptile species). No differences in the species composition, taking into account the exploited minerals, were found but the herpetofauna differ slightly after dividing the opencast mines into sandpits and quarries. Some species were recorded exclusively either in sandpits or in quarries. We also found statistically significant differences in the composition of herpetofauna and separately amphibian species as taking into account the status of exploitation of opencast mines. One species occurred primarily in exploited mines and four only in abandoned ones. No statistical differences between the number of species in exploited, recently abandoned and long since abandoned opencast mines.
\end{abstract}

Key words: amphibians, quarries, sandpits, reptiles

\section{INTRODUCTION}

Region of Lower Silesia is the most abundant in diverse minerals in Poland, which results in a large number of opencast mines in this area (Lorenc \& Mazurek 2010). Nearly 90\% of minerals exploited in the country for road building and production of construction elements come from its deposits (Kaźmierczak \& Kaźmierczak 2012).

Opencast mines display high natural values, in terms of geodiversity or mineralogical and petrographic abundance, they are also habitats of invaluable biocoenoses (Badora et al. 2003). Their landscape, originating from exploitation, in time begins to form microhabitats with conditions (temperature, insolation, humidity, wind action) differing from the surrounding areas not associated with mineral recovery. In result, opencast mines may become more or less attractive to particular species of plants (Czortek 2011) and animals (Majgier et al. 2010). This process leads to development of a specific flora and fauna, including herpetofauna.

In literature, data on the herpetofauna of opencast mines may be found generally in context of large-area inventory studies (e.g. Chlebicki 1988, Majtyka et al. 2010, Kołtowska 2012). Thorough examinations of herpetofauna in single opencast mines or similar mines located within a small area (e.g. Bąbelewska et al. 2014), long-term research of amphibian and reptile colonisation in abandoned opencast mines (e.g. Galán 1997, Ong’oa et al. 2013) as well as in the study of bioindication (e.g. Zhelev et al. 2014).

The aim of our study was to investigate the herpetofauna of opencast mines considering its species richness, whether the bedrocks which are made opencast mines (exploited minerals) and the status of opencast mines (exploited, recently abandoned and long since abandoned) affects the species composition and whether the number of species depending on it.

\section{STUDY AREA, METHODS AND MATERIAL}

We selected 22 opencast mines of six exploited minerals (basalt, granite, marble, quartz, sand and serpentinite), located in lowlands of the eastern part of Lower Silesia, SW Poland (Fig. 1, 
Table 1). We chose both exploited, recently abandoned and long since abandoned opencast mines. These three statuses of exploitation means: exploited - mining works lasted during our observations and vegetation was completely destroyed or occurred only in clumps, recently abandoned - mining works stopped maximum a few years earlier and area overgrown with herbaceous vegetation with few shrubs, long since abandoned - mining works stopped at least a dozen years earlier and area overgrown with herbaceous vegetation, shrubs and trees. In the first case the area is heavily sunny and heats up quickly during the day but cools down quickly at night. In the latter case the area is heavily shaded and there are smaller diurnal temperature ranges. The recently abandoned opencast mines are characterized by a transitional conditions.

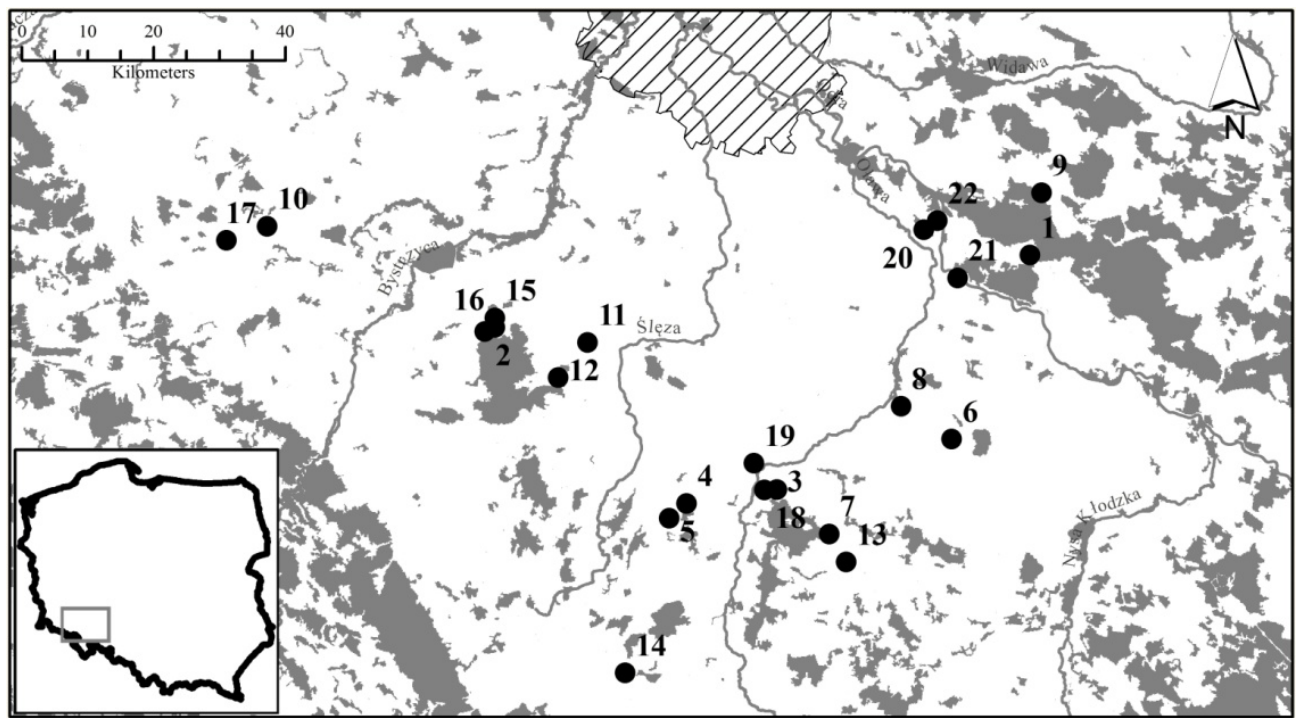

Fig. 1. Study area; dots - opencast mines examined for the presence of herpetofauna, grey - forests, hatched Wrocław, main city in the region.

The opencast mines were inspected in years 2011-2014 between March and October. Each area was carefully searched for the presence of amphibians and reptiles at least a dozen times during that period. Frequency of surveys depended mainly on the size and accessibility of each opencast mine.

In the case of amphibians we observed principally water bodies and their vicinity. The presence of each species were found based on the advertisement calls, the observations of adults and juveniles, larvae or spawns; green frogs were indicated on the basis of morphological features (Krizmanić 2008), colouration (Kierzkowski et al. 2013) and advertisement calls (Juszczyk 1987). Reptiles were looking mainly in sunny and dry places, in herbaceous vegetation or shrubs, basking on the rocks, hunting near water bodies, as well as searching for them under stones, piles of branches and rubbish, i.e. metal plates, rubber mats.

In order to check whether the exploited minerals of which the opencast mines are made and also status of exploitation affects the species compositions we analysed similarities (ANOSIM) between the herpetofauna communities. The Bray-Curtis distance measure was used. The analysis were calculated with PAST 2.17 software (Hammer et al. 2001). The ANOSIM determined whether the species compositions differed statistically between the opencast mines with six extracted minerals (basalt, granite, marble, quartz, sand and serpentinite). Due to the fundamental differences in the structure of the substrate we also carried out an analysis 
distinguishing 7 sandpits (loose ground - sand) and 15 quarries (solid ground - the remaining minerals). We also used the ANOSIM to check whether there are differences in herpetofauna communities between 8 exploited, 3 recently abandoned and 11 long since abandoned opencast mines. To analyse whether the status of opencast mine affects the number of species KruskalWallis test $(\mathrm{H})$ was used. Statistical analyses were performed using the program Statistica 10.0PL (StatSoft, Inc).

Podarcis muralis was removed from the statistical analyses due to the fact that its presence at a given localities is a result of the introduction (Wirga \& Majtyka 2013) and we included to our analyses an observation of Coronella austriaca in 2008 (Kołtowska 2012) in opencast mine no 7.

\section{RESULTS}

We found 14 amphibian species: Ichthyosaura alpestris (Laur.), Lissotriton vulgaris (L.), Triturus cristatus (Laur.), Bombina bombina (L.), Pelobates fuscus (Laur.), Bufo bufo (L.), Bufotes viridis (Laur.), Epidalea calamita (Laur.), Hyla arborea (L.), Pelophylax kl. esculentus (L.), Pelophylax lessonae (Cam.), Pelophylax ridibundus (Pall.), Rana arvalis Nilss., and Rana temporaria L., and 5 reptile species: Anguis fragilis L., Lacerta agilis L., Podarcis muralis (Laur.), Coronella austriaca Laur., and Natrix natrix (L.).

Table 1: The opencast mines examined in 2011-2014 for the presence of herpetofauna in the eastern part of Lower Silesia. Explanations:

Status of land use: E - exploited, RA - recently abandoned, LA - long since abandoned;

Abbreviations used for species: Tc - Triturus cristatus, Lv - Lissotriton vulgaris, Ia - Ichthyosaura alpestris, Bob Bombina bombina, Pf - Pelobates fuscus, $\mathrm{Bb}-$ Bufo bufo, Bv - Bufotes viridis, Ec - Epidalea calamita, Ha - Hyla arborea, Pl - Pelophylax lessonae, Pe - Pelophylax kl. esculentus, Pr - Pelophylax ridibundus, Rt - Rana temporaria, $\mathrm{Ra}$ - Rana arvalis, La - Lacerta agilis, Pm - Podarcis muralis, Af - Anguis fragilis, Nn - Natrix natrix, Ca - Coronella austriaca;

Water body: yes - indicates presence of water bodies suitable for at least one amphibian species, no - indicates absence of water bodies or presence of only large, deep water bodies with shores forming high, vertical walls;

*Species found in 2008 by Kołtowska (2012).

\begin{tabular}{|c|c|c|c|c|c|c|}
\hline No & Coordinates & $\begin{array}{l}\text { Status of } \\
\text { land use }\end{array}$ & $\begin{array}{c}\text { Exploited } \\
\text { mineral }\end{array}$ & $\begin{array}{l}\text { Water } \\
\text { body }\end{array}$ & Amphibians & Reptiles \\
\hline 1 & $50.95^{\circ} \mathrm{N}, 17.42^{\circ} \mathrm{E}$ & $\mathrm{E}$ & sand & yes & Pf, Bv, Ec, Ha, Pe, Rt, Ra & $\mathrm{La}$ \\
\hline 2 & $50.89^{\circ} \mathrm{N}, 16.68^{\circ} \mathrm{E}$ & LA & granite & no & - & La, Af \\
\hline 3 & $50.75^{\circ} \mathrm{N}, 17.08^{\circ} \mathrm{E}$ & LA & granite & no & $\mathrm{Pe}$ & - \\
\hline 4 & $50.74^{\circ} \mathrm{N}, 16.95^{\circ} \mathrm{E}$ & $\mathrm{E}$ & granite & yes & $\mathrm{Bv}$ & La, Nn \\
\hline 5 & $50.73^{\circ} \mathrm{N}, 16.93^{\circ} \mathrm{E}$ & RA & basalt & yes & $\mathrm{Bb}, \mathrm{Bv}, \mathrm{Pe}, \mathrm{Rt}$ & Af \\
\hline 6 & $50.79^{\circ} \mathrm{N}, 17.32^{\circ} \mathrm{E}$ & LA & sand & yes & Lv, Bob, Pf, Bb, Ha, Rt, Ra & $\mathrm{La}$ \\
\hline 7 & $50.71^{\circ} \mathrm{N}, 17.15^{\circ} \mathrm{E}$ & $\mathrm{E}$ & quartz & yes & $\mathrm{Bv}, \mathrm{Ha}, \mathrm{Pe}$ & Af, $\mathrm{Nn}, \mathrm{Ca}^{*}$ \\
\hline 8 & $50.82^{\circ} \mathrm{N}, 17.25^{\circ} \mathrm{E}$ & RA & sand & yes & Lv, Bob, Pf, Bb, Bv, Ha, Pe, Rt & - \\
\hline 9 & $51.01^{\circ} \mathrm{N}, 17.44^{\circ} \mathrm{E}$ & $\mathrm{E}$ & sand & yes & $\mathrm{Bb}, \mathrm{Bv}, \mathrm{Ha}, \mathrm{Pe}, \mathrm{Ra}$ & $\mathrm{La}$ \\
\hline 10 & $50.98^{\circ} \mathrm{N}, 16.38^{\circ} \mathrm{E}$ & LA & granite & yes & Tc, Lv, Bb, Pe & La, Nn \\
\hline 11 & $50.88^{\circ} \mathrm{N}, 16.82^{\circ} \mathrm{E}$ & $\mathrm{E}$ & serpentinite & yes & $\mathrm{Bv}$ & $\mathrm{La}$ \\
\hline 12 & $50.85^{\circ} \mathrm{N}, 16.78^{\circ} \mathrm{E}$ & LA & serpentinite & yes & Tc, Lv, Ia, Bob, Bb, Pe, Rt & Af, $\mathrm{Nn}$ \\
\hline 13 & $50.69^{\circ} \mathrm{N}, 17.17^{\circ} \mathrm{E}$ & LA & marble & no & $\mathrm{Pe}$ & $\mathrm{La}, \mathrm{Pm}, \mathrm{Nn}$ \\
\hline 14 & $50.59^{\circ} \mathrm{N}, 16.87^{\circ} \mathrm{E}$ & LA & marble & no & - & La, Af \\
\hline 15 & $50.90^{\circ} \mathrm{N}, 16.69^{\circ} \mathrm{E}$ & $\mathrm{E}$ & granite & yes & $\mathrm{Bb}, \mathrm{Bv}, \mathrm{Pe}, \mathrm{Rt}$ & $\mathrm{Nn}$ \\
\hline 16 & $50.89^{\circ} \mathrm{N}, 16.69^{\circ} \mathrm{E}$ & LA & granite & no & - & - \\
\hline 17 & $50.97^{\circ} \mathrm{N}, 16.33^{\circ} \mathrm{E}$ & LA & basalt & no & $\mathrm{Pe}$ & La, Nn \\
\hline 18 & $50.75^{\circ} \mathrm{N}, 17.06^{\circ} \mathrm{E}$ & RA & granite & yes & $\mathrm{Bb}, \mathrm{Bv}, \mathrm{Ha}, \mathrm{Pe}$ & La, Pm, Nn \\
\hline 19 & $50.77^{\circ} \mathrm{N}, 17.05^{\circ} \mathrm{E}$ & $\mathrm{E}$ & granite & yes & $\mathrm{Bv}, \mathrm{Pe}$ & $\mathrm{La}, \mathrm{Pm}, \mathrm{Nn}, \mathrm{Ca}$ \\
\hline 20 & $50.98^{\circ} \mathrm{N}, 17.28^{\circ} \mathrm{E}$ & LA & sand & yes & Tc, Lv, Bob, Pf, Bb, Ha, Pl, Pe, Ra & $\mathrm{La}, \mathrm{Nn}$ \\
\hline 21 & $50.93^{\circ} \mathrm{N}, 17.32^{\circ} \mathrm{E}$ & LA & sand & yes & Bob, Pf, Bb, Pe, Pr, Ra & $\mathrm{La}$ \\
\hline 22 & $50.98^{\circ} \mathrm{N}, 17.30^{\circ} \mathrm{E}$ & $\mathrm{E}$ & sand & yes & $\mathrm{Bv}, \mathrm{Ec}$ & - \\
\hline
\end{tabular}


The opencast mines were inhabited by $0-9$ (median $=5$ ) herpetofauna species, comprising $0-8($ median $=3)$ amphibian and $0-4$ (median $=2$ ) reptile species. The maximum number of amphibian species was 8 and maximum number of reptile species was 4 in single mine and in one mine no herpetofauna was observed at all (Table 1).

No statistically significant differences we have found in the species composition of whole herpetofauna, amphibians and reptiles between the opencast mines with different exploited mineral. We have observed statistically significant differences in the species composition in herpetofauna of the opencast mines divided because of its type, i.e.: sandpit or quarry (Table 2). However, we have no found statistically significant differences in species composition of amphibians and reptiles, considering them separately.

We have found statistically significant differences in the composition of herpetofauna, and separately, of amphibians when we took into account the status of exploitation of opencast mines (Table 2).

We did not detect statistical differences in the species number of amphibians $\left(\mathrm{H}_{2,22}=1.80\right.$, $\mathrm{p}>0.05)$, reptiles $\left(\mathrm{H}_{2,22}=0.78, \mathrm{p}>0.05\right)$, and generally of herpetofauna species $\left(\mathrm{H}_{2,22}=1.15\right.$, $\mathrm{p}>0.05)$ considering the status of exploitation of opencast mines.

Table 2. Analyses of similarity (one-way ANOSIM) for the herpetofauna and separately amphibians and reptiles community among the exploited minerals (basalt, granite, marble, quartz, sand and serpentinite) and among the statuses of exploitation (exploited, recently abandoned and long since abandoned opencast mines). Significant levels marked with asterisks

\begin{tabular}{|c|c|c|c|c|c|c|}
\hline \multirow{2}{*}{ Variables } & \multicolumn{2}{|c|}{ Herpetofauna } & \multicolumn{2}{|c|}{ Amphibians } & \multicolumn{2}{|c|}{ Reptiles } \\
\hline & $\mathrm{R}$ & $\mathrm{p}$ & $\mathrm{R}$ & $\mathrm{p}$ & $\mathrm{R}$ & $\mathrm{p}$ \\
\hline Exploited minerals & 0.120 & 0.146 & 0.135 & 0.106 & 0.028 & 0.366 \\
\hline Pairwise comparison & & & & & & \\
\hline Sandpits vs. Quarries & 0.240 & $0.024^{*}$ & 0.130 & 0.098 & 0.067 & 0.196 \\
\hline Status & 0.106 & 0.127 & 0.187 & $0.029 *$ & 0.005 & 0.409 \\
\hline Pairwise comparison & & & & & & \\
\hline Exploited vs. Recently Abandoned & -0.032 & 0.500 & 0.046 & 0.295 & 0.085 & 0.245 \\
\hline Exploited vs. Long since Abandoned & 0.207 & $0.013^{*}$ & 0.340 & $0.002 *$ & -0.057 & 0.783 \\
\hline Recently Abandoned vs. Long since Abandoned & -0.077 & 0.584 & -0.118 & 0.807 & 0.118 & 0.198 \\
\hline
\end{tabular}

\section{DISCUSSION}

In the surveyed opencast mines of Lower Silesia (SW Poland) we found 19 species of herpetofauna (14 species of amphibians and 5 species of reptiles). In the immediate area occur a total of 21 species (14 species of amphibians and 7 species of reptiles) (Głowaciński \& Rafiński 2003, Wirga \& Majtyka 2013). Thus, in the surveyed opencast mines occur slightly less number of herpetofauna species than adjacent areas. Among reptiles we could not find in opencast mines Zootoca vivipara (Licht.) and Vipera berus (L.), but P. muralis has not been found beyond studied opencast mines.

Species observed in most (over 50\%) of localities included B. viridis, $P$. kl. esculentus and L. agilis. Specimens of these taxa were also most frequently encountered, however relevant data on the number of individuals of each species are not available. Commonness of $B$. viridis and L. agilis may be explained by their xero- and thermophilic preferences (Juszczyk 1987). It should be also emphasised that at the discussed site the toad was found mostly in mines and was rare or absent in the surrounding areas (e.g. Majtyka et al. 2010). P. kl. esculentus and $L$. agilis were observed in all the types of mines. The frog, as an eurytopic and dispersive species (Berger 1975), can quickly colonise opencast mines, hence the high frequency of the species.

Our data suggest that minerals from which the opencast mines are made does not significantly affect to species compositions of herpetofauna but that fauna is slightly different 
between sandpits and quarries. It points out that $P$. fuscus and $R$. arvalis were found only in the sandpits. It is symptomatic that these two amphibians burying in loose ground (Juszczyk 1987).

Examination of opencast mines, although in a small number, draws attention to the two facts: $B$. viridis was recorded only in exploited and recently abandoned opencast mines and three newt species and $B$. bombina were recorded exclusively in the abandoned ones. The toad occurs there due to its ecological requirements making it a pioneer species (Indermaur et al. 2009). Which is also important, it can tolerate human presence. We observed that often it uses buildings located at the mining area as shelters and is not bothered by extraction works. After termination of mining activity, the toad persists in the mine mainly due to revegetation process (own observations). Newt populations become extinct as the result of mining and after its termination it takes time for these poorly mobile amphibians to reinhabit the areas. $B$. bombina prefers permanent, shallow and overgrown water bodies (Hofman \& Szymura 1998), while basins of opencast mines are either deep or shallow, but not overgrown, which is the main reason for the low frequency of observations of this species. However, it begins to colonise opencast mines as their water bodies become overgrown with vegetation (own observations). Status of exploitation of the opencast mines does not affect the number of species of herpetofauna. We consider that there are two reasons for this phenomenon: the majority of species occurs in both, exploited and abandoned opencast mines and there is a natural succession of species.

We are aware of the relatively small number of examined opencast mines and uneven number of each bedrocks therefore all these preliminary conclusions should be confirmed on a larger number of opencast mines. Because of its secretive lifestyle, Coronella austriaca is a hardly detectable species, so it is possible underestimation of its presence on the part of examined opencast mines.

Opencast mines provide specific microhabitats which often serve as refuges suitable for species occurring near the limit of their distribution range, e.g. from Poland - Bombina variegata (L.) in the Sudetes (Hebda 2003), Rana dalmatina (Fitz.) in the Subcarpathia (Starzyk \& Durak 2007) and Zamenis longissimus (Laur.) in the Bieszczady Mountains (Błażuk 2007). It is also worth noting that eight species which we found are strictly protected by law in Poland (Grabowski 2014) and reclamation of opencast mines, regardless of its form or direction, imposes a threat to amphibians and reptiles inhabiting such areas. Abandoned opencast mines should either not be recultivated, to allow natural succession of species, or interfered only to an extent still preserving habitats of rare species.

\section{ACKNOWLEDGEMENTS}

We are thankful to anonymous reviewers for their valuable comments.

\section{REFERENCES}

BADORA K., HEBDA G., NOWAK A. \& NOWAK S. 2003. Różnorodność biologiczna i geologiczna wyrobisk poeksploatacyjnych skał węglanowych górnej kredy miasta Opola. Nature Journal, Opole Scientific Society, 36: 35-67.

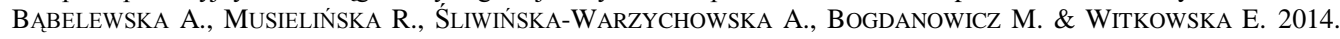
Edukacyjna rola nieczynnego kamieniołomu „Lipówka” w Rudnikach koło Częstochowy. Prace Komisji Krajobrazu Kulturowego 26: 57-66.

Berger L. 1975. Fauna słodkowodna Polski. Gady i płazy (Reptilia et Amphibia). Państwowe Wydawnictwo Naukowe, Warszawa, 110 pp..

BŁAŻUK J. 2007. Herpetofauna doliny Sanu pod Otrytem i terenów przyległych (Bieszczady Zachodnie). Roczniki Bieszczadzkie 15: 181-229.

CHLEBICKI A. 1988. Herpetofauna Wzgórz Strzelińskich na Dolnym Śląsku. Acta Universitatis Wratislaviensis 972 , Prace Zoologiczne 19: 37-52.

CzORTEK P. 2011. Encroachment of thermophilous species on the transformed habitats (sand and gravel pits) near Świecie on the Vistula. Annales Universitatis Mariae Curie-Skłodowska Lublin Polonia, Sectio C 66: 121-133.

GALÁN P. 1997. Colonization of spoil benches of an opencast lignite mine in northwest Spain by amphibians and reptiles. Biological Conservation 79: 187-195. 
GŁOWACIŃSKi Z. \& RAFIŃSKi J. (eds) 2003. Atlas płazów i gadów Polski. Status - rozmieszczenie - ochrona. Główny Inspektorat Ochrony Środowiska, Instytut Ochrony Przyrody PAN, Warszawa-Kraków, 152 pp.

GrabowsKi M. H. 2014. Rozporządzenie Ministra Środowiska z dnia 6 października 2014 r. w sprawie ochrony gatunkowej zwierząt. Dziennik Ustaw Rzeczypospolitej Polskiej, poz. 1348.

HAMmer Ø., HARPER D. A. T. \& RYAN P. D. 2001. PAST: Paleontological statistics software package for education and data analysis. Palaeontologia Electronica 4: 1-9.

HebDa G. 2003. Rozmieszczenie kumaków Bombina Oken, 1816 na Opolszczyźnie. Nature Journal, Opole Scientific Society, 36: 77-82.

Hofman S. \& Szymura J. M. 1998. Rozmieszczenie kumaków, Bombina Oken, 1816 w Polsce. Przegląd Zoologiczny 42: $171-185$.

Indermaur L., Gehring M., Wehrle W., Tockner K. \& NAEF-DAenZer B. 2009. Behavior-Based Scale Definitions for Determining Individual Space Use: Requirements of Two Amphibians. The American Naturalist 173: 60-71.

JuszCZYK W. 1987. Płazy i gady krajowe. Vol. 1-3. 2nd ed. rev. Państwowe Wydawnictwo Naukowe, Warszawa, pp. $238+384+214$

KAŹMIERCZAK U. \& KAŹMIERCZAK W. 2012. Ocena dolnośląskiego górnictwa skalnego w latach 2003-2011. Prace Naukowe Instytutu Górnictwa Politechniki Wrocławskiej 134: 143-152.

KierzKowski P., Kosiba P., RyBACKi M., SOCHA M. \& OGIELSKA M. 2013. Genome dosage effect and colouration features in hybridogenetic water frogs of the Pelophylax esculentus complex. Amphibia-Reptilia 34: $493-504$.

KoŁtowsKa M. 2012. Herpetofauna Wzgórz Strzelińskich i okolic w latach 2007-2008. Przyroda Sudetów 15: $113-134$.

KRIZMANIĆ I. I. 2008. Water frogs (Rana esculenta complex) in Serbia - morphological data. Archives of Biological Science Belgrade 60: 449-457.

LorenC M. W. \& MAZUREK S. 2010. Wybrane, nowe propozycje atrakcji geoturystycznych z Dolnego Śląska. Geoturystyka 22-23: 3-18.

MAJGIER L., BADERA J. \& RAHMONOV O. 2010. Kamieniołomy w województwie śląskim jako obiekty turystycznorekreacyjne na terenach uprzemysłowionych. Problemy Ekologii Krajobrazu 27: 267-275.

MAJTYKa T., GóRAJEWSKa J., KorDAS J. \& OGIELSKA M. 2010. Herpetofauna Ślężańskiego Parku Krajobrazowego i okolic. Przyroda Sudetów 13: 193-202.

Ong’oA D. O., NG’endo R. N., Muya S. M., Nyoike M. M., Malomz P. K. \& Osiemo Z. L. 2013. Diversity and abundance patterns of amphibians in rehabilitated quarries of Bamburi near Mombasa (Kenya). Transylvanian Review of Systematical and Ecological Research 15: 61-72.

STARZYK N. \& DURAK R. 2007. Nowe stanowisko żaby dalmatyńskiej Rana dalmatina Bonaparte w południowowschodniej Polsce. Przegląd Zoologiczny 51: 51-55.

WIRGA M. \& MAJTYKA T. 2013. Records of the Common Wall Lizard Podarcis muralis (Laurenti, 1768) (Squamata: Lacertidae) from Poland. Herpetology Notes 6: 421-423.

Zhelev Zh., ARnAudov At. \& BoyAdZhiev P. 2014. Colour polymorphism, sex ratio and age structure in the populations of Pelophylax ridibundus and Pseudepidalea viridis (Amphibia: Anura) from anthropogenically polluted biotopes in southern Bulgaria and their usage as Bioindicators. Trakia Journal of Sciences 1: 1-12.

\section{STRESZCZENIE}

\section{[Herpetofauna kopalń odkrywkowych na Dolnym Śląsku (Polska)]}

Herpetofauna kopalń odkrywkowych jest słabo poznana i brak jest wcześniejszych kompleksowych badań $\mathrm{w}$ tej dziedzinie. Celem pracy było zbadanie tej fauny na przykładzie wybranych wyrobisk. Obserwacje, prowadzone w 22 kopalniach odkrywkowych we wschodniej, nizinnej części Dolnego Śląska (pd.-zach. Polska), wykazały łącznie 19 gatunków (w tym 14 gatunków płazów i 5 gatunków gadów). Brak istotnych różnic w składzie gatunkowym, w odkrywkach podzielonych ze względu na wydobywane minerały, natomiast daje się zauważyć niewielkie różnice składu gatunkowego herpetofauny pomiędzy piaskowniami a kamieniołomami. Niektóre gatunki zostały zaobserwowane wyłącznie albo w piaskowniach albo w kamieniołomach. Znaleźliśmy również istotne statystycznie niewielkie różnice w składzie gatunkowym herpetofauny i samych płazów uwzględniając stan eksploatacji kopalń odkrywkowych. Jeden gatunek występuje głównie w eksploatowanych odkrywkach a cztery inne tylko w opuszczonych. Nie stwierdzono natomiast istotnych statystycznie różnic między liczbą gatunków w kopalniach odkrywkowych eksploatowanych, niedawno opuszczonych i dawno opuszczonych. 